\title{
Conversion to organic farming: a multidimensional research object at the crossroads of agricultural and social sciences. A review
}

\author{
Claire LAMINE ${ }^{1}$, Stéphane BELLON ${ }^{2}$ \\ ${ }^{1}$ INRA, UAR Éco-Innov, BP 01, 78850 Thiverval-Grignon, France \\ 2 INRA, UR 767 Écodéveloppement, Site Agroparc, 84914 Avignon Cedex 9, France
}

(Accepted 7 January 2008)

\begin{abstract}
Literature on the conversion from intensive to organic farming is scarce. However, both the conversion of farmers to organic farming and of consumers to organic food are the driving forces for the development of the organic sector. In this review, we combine agricultural and social scientists' viewpoints for a critical appraisal of literature on conversion to organic food and farming. First, a brief historical retrospective enables us to refer the scientific production to the institutional and economic context over the past decades. Secondly, we review the methods used to analyse conversion in agricultural and social sciences, and show that emphasis is most often laid upon the effects of conversion and the motivations to convert, on the basis of comparative approaches with so-called conventional agriculture. Therefore, the literature minimises the importance of transitional aspects and trajectories, and rarely approaches conversion as a longer process than its legal duration and from a wider point of view. Thirdly, we examine the paradigms of input efficiency and system redesign, which frame discussions about transitions in agriculture, beyond organics, and therefore helps shed light on sustainability issues. We suggest that analysing conversion and more generally transitions in agriculture as multidimensional issues, involving both production and social practices, entails interdisciplinary approaches and the redefinition of some central research topics.
\end{abstract}

organic food and farming / conversion / transition / conventionalisation thesis / interdisciplinarity / redesign

\section{INTRODUCTION AND SHORT RETROSPECTIVE}

Conversion to organic production is most often defined through regulations. It involves a given time span as well as specific constraints and procedures, whereby organic principles must be applied to parcels and animals for two or three years. For farmers though, conversion does not restrict itself to this period and these technical procedures codified by regulations, but entails transformations which transcend this legal period and definition. These transformations also go beyond the technical level and concern farmers' conceptions, values and inscription in social networks. Therefore, the first objective of this literature review focused on the English- and French-speaking worlds is to show how agronomy and sociology have dealt with the issue of conversion, to present the approaches and methods used in each field, to enhance more extensive approaches and to capture the different versions of organic farming in practice, in opposition to a sometimes homogenising vision of organics. For this latter reason, we will refer to organics when we need to encompass organic farming and organic consumption in their diversity. Beyond organics itself, our second objective is to assess conversion to organic farming as a more general transition model towards more sustainable agriculture and to point out relevant approaches and needs for further research.

Firstly, a short historical retrospective of both agronomical and sociological literature during the last three decades, that is, a generation of organic farmers and consumers, is suggested. Secondly, we present the methodological approaches of conversion developed both in agronomy and in sociology, and find that conversion is mainly analysed in terms of effects and motivations, at the expense of more comprehensive approaches. Finally, we show how some recent studies on organics, mainly centred on questions of conventionalisation and paradigm changes, enrich the debates on the different forms of sustainable agriculture and enhance the need for more comprehensive and interdisciplinary approaches.

Conversion, both of a given farmer or on a larger scale, must be related to the general dynamics of organic farming. Converting to organic farming in the 1970s, when there 
was no label, is completely different from converting in the XXIth century. The process of "institutionalisation" of organic farming started very progressively from the 1960s and lead to a relative regulatory harmonisation on a European scale with the 2092/91 regulation, despite the national specificities due to the national policies to support organic farming (Lampkin and Stolze, 2006) or to the organisation of specific professional and associative structures, as acknowledged for the USA (Vos, 2000), the UK (Reed, 2001), Belgium and Denmark (Lynggaard, 2001) or France (Piriou, 2002).

How does the literature reflect this evolution of organics? The founding fathers of organic farming published their work from the 1920s (R. Steiner's Spiritual Foundations for the Renewal of Agriculture dates back to 1924) to the 1940s (An Agricultural Testament by A. Howard is from 1940) (Besson, 2007). Then there was a gap in publications until the 1970s, where most of the research work in organics was carried out by private institutions. From the 1970s until today, the literature can be organised in three main blocks: (i) pioneering studies, mainly from the 1970s and 1980s, seeing organic farming as an alternative model or criticising its feasibility; (ii) from the mid-1990s on, articles analysing the specialisation of organic production and debating its conventionalisation; and finally, (iii) in the recent period, promising approaches which appear to be more extensive.

In the 1970s, several pioneering studies, in agronomy as well as in sociology, strove to describe this new fact that was the development of organic farming on the agricultural scene. In the field of agronomy, organic farming has been studied through its performances (Sebillotte, 1972, 1974), leading to a critical vision disregarding organic farming as a genuine agricultural alternative. Although this vision remained relatively dominant, other authors tried to rehabilitate organic agriculture and the farmers who practised it by analysing its technical foundations and subsequent balances, i.e., organic and mineral fertilisation, labour, assets, and liabilities (Bellon and Tranchant, 1981; Lockeretz, 1981), by looking at it as a social and economic practice and by acknowledging its technical and regional diversity (Cadiou et al., 1975). In this literature, organic farming is found to be a feasible alternative to conventional models (Viel, 1979; Gautronneau et al., 1981). In the USA, in this period of questioning over the limits of socalled modern agriculture, organic agriculture was considered a possible model (USDA, 1980), and other qualifications and definitions for agriculture also emerged, in particular "sustainable" (Harwood, 1990) and "alternative" agriculture (National Research Council, 1989). These French and American studies favoured a holistic approach enhancing the relationships among crop rotations, tillage methods, pest control and nutrient cycling, which is part of a more general and lasting shift in research programmes towards the use of systemic analysis (Bellon et al., 1985; Norman and Malton, 2000). In the field of sociology, several studies, in the USA and in France, tackled organic farmers' attitude and practices (Harris et al., 1979; Barrès et al., 1985; Le Pape and Rémy, 1988). While later studies on conversion were mostly centred on the analysis of farmers' motivations, these pioneering studies suggested a more extensive vision of conversion which put forward the social and biographical factors that led farmers to convert in a professional context that was largely reluctant.

If the study of organic farming seriously declined in the 1980 s, it came back onto the scientific scene in the 1990s when it became codified and acknowledged by laws and institutions. A bibliometric analysis built from the "ISI expanded" base created in 1991 shows a multiplication of publications related to organic farming between 1992 (47 publications) and 2004 (224 publications) i.e. a significantly higher increase than literature concerning agriculture in the same database. The journals having published more than 40 articles about organic farming in this period are "Agriculture Ecosystems \& Environment" (71 articles), "Biological Agriculture \& Horticulture" (70) and "Biology and Fertility of Soils" (41), (Bonneuil, 2004). These articles deal mainly with assessments of organic farming (the effects on biodiversity, nutrient cycles and energy consumption) and its spatial relations to the environment (e.g., the role of hedges and grass strips).

Other authors describe the increasing specialisation of organic farms (Allard et al., 2001), the consequent accentuation of technical problems such as weed control and fertilisation management and the parallel specialisation of research, development and extension, leading to a focus on a commodity approach to organics, as for livestock (Hovi and Garcia Trujillo, 2000; Roderick, 2004) and fruit production (Gigleux and Garcin, 2005). Social scientists rather put the accent on the processes of "conventionalisation", whereby organic production and markets are being overcome by large-scale structures and becoming more and more vertically integrated, just like in conventional agriculture.

In recent years, more comprehensive approaches to organic farming but also, broadly speaking, to organic food systems have been developed. In the social sciences several authors point out the necessity to study the links between production and consumption, when talking about the evolution of agro-food systems, as it is discussed within the "productionconsumption debate" (Lockie, 2002; Goodman, 2003). Biological and agricultural scientists contributed to the enlargement of this debate by suggesting an approach that, beyond a restricted agronomic vision limited to the field or at best to the farm, would encompass natural phenomena such as climate change (Flessa et al., 2002) and social aspects linked to food consumption (Gliessman, 1997; Francis et al., 2003).

This brief retrospective as well as the increasing number of publications in agricultural journals and the richness of organic workshops in several recent rural sociology congresses (Holt and Reed, 2006) reveal that, particularly since it became framed by law, organic farming has become a scientific subject in both agricultural and social sciences. However, despite the large number of studies concerning organic farming, and despite the diversity of approaches, conversion in itself is not a subject of study in agronomy. Social scientists seem to have been more prolific on this subject, even though we will see that their analyses often stick to the classical marketorientated/values-orientated opposition. 
Table I. Main topics and approaches identified on organic farming and environmental issues.

\begin{tabular}{|c|c|c|}
\hline Environmental topics & Approach & References \\
\hline \multicolumn{3}{|l|}{ Soil quality } \\
\hline Physical, chemical and biological measurements & $\begin{array}{l}\text { Long-term trial (as from 1978, study of biodynamic, organic, } \\
\text { and conventional) }\end{array}$ & Mäder et al. (2002) \\
\hline Chemical and biological properties & Two adjacent fields ( 7 years of organic certification) & Marinari et al. (2006) \\
\hline Soil organic carbon accumulation rates & Ten cropping systems and native ecosystems (LTER site) & $\begin{array}{l}\text { Grandy and Robertson } \\
\text { (2007) }\end{array}$ \\
\hline \multicolumn{3}{|l|}{ Nutrient management } \\
\hline $\mathrm{N}$ leaching and balances & Modelling approaches (function and balance) at system level & Hansen et al. (2000) \\
\hline $\mathrm{N}$ balance at farm level and reduction of potential $\mathrm{N}$ losses & Three scenarios with relative conversion in a local area & Dalgaard et al. (2001) \\
\hline Effect of cash crops on sulphate leaching & 3-year trial in low-input systems & $\begin{array}{l}\text { Eriksen and Thorup- } \\
\text { Kristensen (2002) }\end{array}$ \\
\hline $\begin{array}{l}\text { Input-output balances for macronutrients }(\mathrm{P}, \mathrm{K}, \mathrm{Mg}) \text { and } \\
\text { trace elements }(\mathrm{Cd}, \mathrm{Cu}, \mathrm{Zn})\end{array}$ & Field trials in adjacent dairy systems on experimental farm & Bengtsson et al. (2003) \\
\hline
\end{tabular}

\begin{tabular}{ll}
\hline Activity density and diversity of carabids and staphylids & $\begin{array}{l}\text { Two field experiments over periods of } 6 \text { and } 8 \text { years during Andersen and Eltun } \\
\text { conversion }\end{array}$ \\
Structural and functional diversity at farm level & $\begin{array}{l}\text { Indicators of cropping system biodiversity on } 33 \text { farms (18 Caporali et al. (2003) } \\
\text { organic) in 2002 }\end{array}$
\end{tabular}

Species richness and abundance

Meta-analyses based on 66 publications with paired compar- Bengtsson et al. (2005)

Impacts on biodiversity of organic farming isons between the two systems

Review of 76 comparative

Hole et al. (2005)

studies of the two systems, across a broad range of taxa

Relations between weed communities, management vari- Comparison between two weed surveys (in the 60s and late Hyvönen (2007)

ables and site conditions 90s)

\begin{tabular}{l}
\hline Greenhouse gas emissions \\
\hline Aggregate greenhouse gas emission (CO2, CH4 and N2O) \\
\hline Energy consumption \\
\hline Energy use as an indicator of the intensity of production \\
processes \\
Several environmental compartments \\
\hline Soil properties, ecosystem biodiversity, water quality, use \\
on non-renewable resources \\
Soil organic matter, N and P leaching and balances, biodi- \\
versity \\
Strengths and risks of organic farming (soil, water, land- \\
scape diversity, water utilisation) \\
\hline \\
2. METHODS APPLIED TO ANALYSING \\
CONVERSION IN AGRICULTURAL \\
AND SOCIAL SCIENCES
\end{tabular}

The majority of studies published in agronomical journals approach conversion in terms of its effects much more than in terms of a dynamic process. These effects are usually analysed through two approaches. The first one uses a conventional reference so as to assess possible differences among situations and to understand underlying processes. The second approach uses intra-organic comparison without referring to conventional agriculture. Case studies are favoured, arguing that organic farming is site-specific. Case studies also enable a better identification of research hypotheses according to real farm dilemmas (Lampkin, 1986; Loes, 1990). Methods in both approaches entail on-farm surveys and experiments in agricultural stations so as to analyse the effects of conversion on particular environmental compartments or on agronomical and sometimes economic performances. The review of these two types of approaches points out the necessity of long-term and farm-scale studies and the interest of interdisciplinary studies to take into account the internal dynamics of organic farming.

\subsection{Studies comparing organic farming with other forms of agriculture}

Several studies evaluate the effect of organic farming on various environmental compartments with balances, indicators and models, or based on scenarios. Most of them rely on comparisons with conventional agriculture (Tab. I).

Studies comparing organic farming with other forms of agriculture gave rise to numerous articles, but few of these directly deal with the conversion period. Yield differences between a reference in conventional agriculture and/or one in integrated production are often a focus of attention. For example, Lotter et al. observed that the economic margin of an organic maize was better than for a conventional one in 4 out 
of 5 years, but those years were affected by drought (Lotter et al., 2003). Above all, when compared with farms which are poorly managed, organic agriculture will generally give better yields, and vice versa. This raises the question of the comparability and the representativity of studied situations.

Comparative studies can therefore lead to contradictory results concerning the evaluation of organic agriculture as compared with other modes of production. Their assumptions and their specific experimental conditions, as well as the generalisation of their results, have been largely criticised (Elliot and Mumford, 2002; Kirchman and Ryan, 2004; Martini et al., 2004; Trewavas, 2004). Another limit of comparative tests is that they do not really take into account either the interactions between management, crop varieties and site-specific effects, the externalities (environment, energy, health) or the systemic properties (autonomy, resilience, stability). Organic agriculture is often interpreted - in experimental conditions - through the absence of chemical products. Moreover, conversion is restricted to its legal duration. Conversely, the few experimental studies which have taken into consideration the dynamics of organic conversion through the construction of successive balances over longer periods of time were published in renowned journals (Reganold et al., 2001; Mäder et al., 2002). In their literature review on biodiversity, Hole et al. (2005) suggest that there may be a time lag in the response of wildlife communities to any benefits generated by a switch from conventional to organic farming. They also assume that those farmers who choose to convert may be pre-disposed to environmentallyfriendly farming practices in the first place or may farm land that has previously been managed less intensively and is therefore easier to convert successfully to organic. They finally advocate the need for longitudinal studies that assess the capacity of organic conversion to reverse previous biodiversity losses caused by intensification.

In these comparative studies, the diversity and the internal dynamics of organic agriculture are often ignored (Sylvander et al., 2006), as if it were a homogeneous whole, except in the case of a few recent articles (Petersen et al., 2006; Rasmussen et al., 2006). Recognising the diversity of situations is actually difficult for comparisons over several years. Does the experimental comparison of several organic systems allow a better accounting of this internal diversity and these dynamics? Such an approach has been put in place for the case of livestock, where two systems were compared: a grassland system with limited production objectives and a mixed cropping-livestock system with higher production objectives (Benoît et al., 2005; Coquil et al., 2006). In a similar perspective, Benoît and Veysset (2003) tested the notion of conventionalisation through the application of a conventional sheepbreeding pattern ( 3 lambing periods per ewe every two years) in organic sheep meat production. This option, which aimed at maximising the productivity, finally appeared as inadequate due to its complex implementation, in particular with dependence on external inputs, variability in performances and lower margins of security in an accelerated sheep production system. In short, implementing such an intensive breeding pattern in organic agriculture is difficult because it introduces a supplementary constraint in a system already highly constrained. Taking the farm into consideration over time can render this conclusion more specific, though. If farmers were already following an intensive breeding pattern before conversion, switching to organic management might be easier; however, they will not have the same ways as in conventional agriculture to face difficulties (Cabaret et al., 2002). If farmers convert from a grazing-based and seasonal breeding system, then switching is all the more difficult.

In field crop production, other ways to approach the subject are considered so as to improve the methods; for example, through comparisons between cropping systems (Vereijken, 1997) and through the integration of the environment of compared plots and farms (Marshall and Moonen, 2002). A more radical proposal favours comprehensive studies of organic agriculture to comparative studies which are dominantly descriptive. This enables the design of subsidiary hypotheses, and the identification of topics for further studies of underlying biotechnical processes in order to derive more general principles (Wynen, 1996; Kristiansen, 2006). A clear identification of the specific objectives and constraints of organic agriculture - rarely formalised in research projects - could help with rethinking organic agriculture but also other forms of agriculture. We agree that it is a major stake for organic agriculture, i.e., to construct and characterise innovations which can serve other forms of sustainable agriculture.

\subsection{Longitudinal studies specific to organic farming}

These studies develop comparisons between organic farms after their conversion, through case studies (Bellon and Tranchant, op.cit.) or typologies (Langer, 2002). The central subject is the effect of conversion on production and the interannual variability of the yields. Several studies reveal that yields do not always increase several years after conversion (Stanhill, 1990; Stolze et al., 2000). This finding is controversial, as results may vary according to the cropping systems and the regions under consideration. In the mid-term, when a different soil functioning has been put in place, yields are somewhat higher or comparable with those obtained before switching from conventional to organic management, as shown by Zundel and Kilcher (2007) in a bibliographical review. They also suggest that a decrease in yields during the legal period of conversion depends on the previous intensification level of cropping systems. The "depressive effect" would be stronger in formerly high-input systems.

The role of soil in conversion has been pointed out by several authors (Liebhardt et al., 1989; MacRae et al., 1990) who mention an "organic transition effect". This effect would lead to a reduction in technico-economic performances early in the organic conversion (ecological processes being inadequate to supply nutrients, to control pests and diseases, or to provide essential functions previously provided by chemical inputs). Afterwards, soil properties and biological activity would improve after 3 or more years of organic management, which in turn would give higher yields.

Martini et al. (2004) discuss this "soil-quality hypothesis". They compare identically managed organic systems, differing 
only in the number of years since being converted to organic farming (less than 1 year and more than 5 years), with a 2-year crop rotation of processing tomato and maize. No significant differences appeared in tomato yields as related to the year of conversion. Organic tomato yields were also superior to a conventional reference. On the other hand, soil chemical properties ( $\mathrm{P}, \mathrm{K}$, total $\mathrm{N}$ and total $\mathrm{C}$ ) were superior in the plots which had been converted for more than 5 years. Such properties might have little effect on yield once some minimum threshold is achieved, for instance due to past practices. These authors suggest that the increasing experience of farmers after conversion can have a determining effect, which highlights that previous yield comparisons among years may also reflect learning processes in organic farming. However, they point out that the extrapolation of such results beyond specific experimental conditions is risky without additional controlled comparisons between replicated plots.

In accordance with organic principles, crop rotations are also particularly focused on (Bulson et al., 1996; Bertsen et al., 2006; Papadopoulos et al., 2006). In the process of converting, indeed, soil fertility has to be built up through the effects of preceding crops, particularly on stockless farms. Crop sequences influence soil fertility and nutrient cycles; they also protect crops from risks of infestation by weeds, pests and diseases; and they contribute to seedbed preparation. Huxham et al. (2004) tested in specialised field crop systems the effects of seven conversion strategies, defined by couples of preceding crops, on a subsequent winter wheat and on two different kinds of soils. They noticed significant yield differences in wheat ( 2.8 to $5.3 \mathrm{t} / \mathrm{ha}$ ) according to the strategy. Higher wheat yields were obtained after a Red clover-Ryegrass (Lolium perenne L.) green manure. These authors conclude on the importance of the crop establishment phase of the first wheat crop following conversion, and show that preceding effects on wheat yields are mediated by soil structure.

The evaluation of organic farming performances solely through yields, which is the focus of most studies, is questionable, as this production mode also targets other objectives (effects on the environment, quality of products and new relations with consumers). Indeed, some authors argue that organic farming is multi-targeted and add criteria concerning agricultural labour, product quality or environmental friendliness (Niggli et al., 2007).

Morover, some case studies, most often carried out on the regional scale, deal with economic or environmental results of conversion and adaptations after conversion of livestock farms. The range of situations which is studied is enlarged in comparison with monitoring on commercial farms or experimental stations. In this perspective, other authors suggest using methods adapted to the assessment of longer-term consequences of conversion, such as simulation (Dabbert et Madden, 1986; Dalgaard et al., 2001; Benoît and Veysset, 2003) or modelling (Rosegrant et al., 2006).

\subsection{The necessity of long-term and farm-scale studies to analyse the dynamics of conversion}

The notion of stability, which is an underlying concept in agronomical studies that compare organic and conven- tional systems, does not suit the analysis of conversion. Such studies rely on a Cartesian scientific paradigm which reduces the factors of variation in the environment and circumscribes the subject to a controllable system, whereas conversion, on the contrary, enhances natural regulation processes and an evolutionary relationship to techniques.

When conversion is studied in itself rather than through its effects, its time span is formal and fixed, whereas its duration actually depends on specific situations, and its term is not a given. Therefore, the transitional dynamics are neglected. To take them into account, the construction of new balances should be described, with the identification of new combinations of productions in space and over time, of subsequent states in the field and its environment (Sjursen, 2001), and of techniques to manage or master pests and diseases (Zehnder et al., 2007); all consistent with a revision of agronomical and economic performances.

For example, based on comprehensive studies of 29 converting farmers, Bonnaud et al. (2000) identify three types of trajectories: (i) reinforcement of a farm transformation which was already undertaken, with environmentally-friendly and close-to-organic practices; (ii) direct conversion to organic farming, often with strategies of direct marketing; and (iii) branching out towards a new orientation, whether breaking with past practices and experiencing alternative management methods into new networks, or searching for new combinations of farm activities. The first type can be considered as an organic agriculture " by default" and does not really imply a profound change of mind. It represents probably a larger potential base for the development of organic farming than the two other types, but supposes that producers and advisers take seriously the principles of organic farming and really apply them for the further evolution of the converted farms.

From a methodological point of view, farm or field pluriannual monitoring and modelling can contribute to this objective. However, monitoring is costly and not always achieved in this perspective. The reference to a situation preceding the conversion relies more often on a reconstitution than on the analysis of collected data, except in the few cases where monitoring had been started before a conversion that was actually not anticipated. Modelling can also be useful to simulate potential farm evolutions and changes in scales.

Besides the importance of long-term studies, the scale on which these studies are carried out is also fundamental. The farm scale is considered as relevant in most research work (MacRae et al., 1990) and in European regulations (EEC 2092/91). In the new regulation adopted (EEC 834/2007), the general rules concerning conversion are unchanged. Both the implementation and exception procedures of this regulation still favour the scale of the plot, the crop or the animals as elementary units. However, several authors highlight the advantages and the constraints of system approaches on the farm scale (Lockeretz, 1985, 1987; David, 1999). In particular, Lockeretz and Stopes (1999) analysed on-farm research in organic farming spread over different regions, and listed the reasons motivating these approaches as well as their limits. Some arguments in favour of on-farm research are also relevant for the study of conversion: to work over a large range 
of situations of production, to study the long-term effects of a production method, to shed light on farmers' experience and to anticipate the relevance of new technologies. These on-farm system approaches also exhibit limits: difficulties of coordinating on-farm monitoring and exploring highly variable situations, as compared to experimentations in stations. The authors suggest how to link on-farm research and experiments in controlled environments. Lastly, they point out the existing gap between the methodological intentions of these on-farm research projects, which enhance a "systemic approach", and actual research practices.

\subsection{In the social sciences: towards the analysis of trajectories and transitional processes}

In the social studies, three main approaches to conversion can be identified: (1) quantitative analyses of motivations, generally based on the study of farmers' attitudes; (2) identification of decision-making processes during conversion, generally restricted to its administrative period; and (3) qualitative approaches considering conversion over a longer time period and from a wider point of view.

The first series of studies use quantitative methods to analyse attitudes towards organic farming or food, such as Likert scales, which offer contrasted items to which respondents are asked to agree or disagree. Such studies compare organic and conventional farmers' attitudes, "potential converters" and organic farmers, or recent and more experienced converters (Best, 2005; Koesling et al., 2005; Lockie and Halpin, 2005). Most analyses of motivations for conversion reveal that economic motivations surpass environmental as well as food quality motivations, even though the latter two are more often expressed by organic farmers than by conventional ones. Therefore, studies of motivations often lead to a classical opposition between market-orientated farmers and valuesorientated ones, even in qualitative studies (Lund et al., 2002). This opposition does not acknowledge the complexity of farmers' motivations. Alroe and his colleagues suggest that there is a third perspective, besides the two quite common perspectives of, respectively, organics as a market niche and organics as a "heterogeneous protest" bringing together diverse reactions against mainstream practices and developments, which corresponds to organic agriculture seen as an "autopoietic movement" in the sense that it is rendered coherent by way of a common meaningfulness, as expressed in the core values, worldviews and alternative practices of organic actors (Alroe and Kristensen, 2002; Alroe, 2005). Padel also suggests another way to categorise farmers' motivations, by distinguishing technical and financial motivations linked to the farm itself from personal motivations which can be called ethics- or values-orientated, including health, environment and rural development, and finally, lifestyle motivations (Padel, 2001).

We identified a second type of approach. It is based on the conversion decision process, and seems to provide a more suitable method, as it considers that the decision to convert entails several kinds of intricate motivations, whereas attitude studies generally consider the motivations as quite independent from each other. Indeed, these approaches analyse the chain of motivations mainly through the use of decision-tree methods (Gladwin, 1989). The method is comprehensive and aims at identifying farmers' rationale for their actions as well as taking into account the heterogeneity of decision criteria. The results are often presented through farmers' typologies, as for attitude studies. This way, pragmatic organic farmers and committed organic farmers can be distinguished - where the same kind of opposition between market and values can be found again - the first ones being able to go back to conventional farming if price premiums were to diminish (Fairweather, 1999; Darnhofer et al., 2005).

These two first types of approaches consider farmers as relatively isolated rational actors, whereas they are, of course, involved in complex social and professional networks. In addition, conversion is seen as a limited period of time, just like in many agronomical studies, and the real length of the transitional process of conversion, as well as the possible antecedents preceding conversion and the adjustments following it, are all often neglected.

The third type of sociological approach addresses these shortcomings better. It involves studying conversion through qualitative methods based on comprehensive interviews, allowing the identification of biographical events progressively leading to conversion as well as the analysis of farmers' conceptions of their work. Instead of typologies, this third approach favours the tracing of organic farmers' trajectories and the study of their practices (Guthman, 2000). These approaches also analyse learning processes throughout the period of conversion considered over time and study the networks in which farmers are possibly involved. As pioneering studies of the 1970s have already highlighted, farmers are not alone and their commitments to various networks, such as organic farmer groups but also local farmer groups, as well as their meaningful relationships to a variety of actors, i.e., other farmers, consumers, advisory services, neighbours, etc. have to be analysed.

The question of local reputation and the nature of the links with other local farmers are particularly important to assess. Indeed, sociological studies since the beginning of organics often inquire whether organic farmers form a marginal professional group or are, on the contrary, well linked to the rest of the profession. Some authors tend to consider them as a marginal group, because their conceptions of farming are clearly opposed to mainstream agriculture and its modern scientific rationality characterised by the growing use of fertilisers and pesticides (Michelsen, 2001). Organic farmers, especially biodynamists, would have weak relationships with their peers, precisely because they are very critical towards their own profession (MacMahon, 2005). Other authors, though, observe an improvement in organic farmers' relations to the agricultural profession and a willingness to be implied in its networks, even though relationships are often analysed as being closer to consumers than to non-organic farmers (Padel, 2001; Piriou, 2002; Storstad and Bjørkhaug, 2003).

Lastly, the role of advisory services in conversion processes is quite underestimated in the literature even though it often appears as determining when studying organic farmers' 


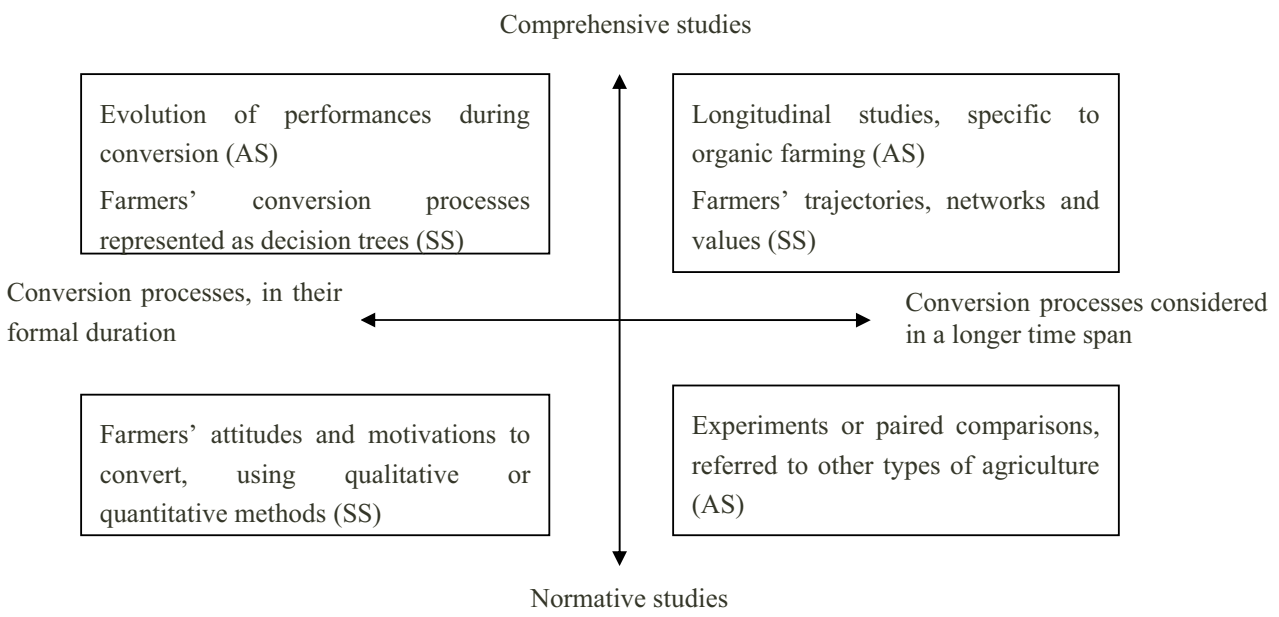

Figure 1. Main approaches to conversion in agricultural sciences (AS) and social sciences (SS). The horizontal axis opposes studies on formal conversion itself (a few years) to those considering a longer time span (beyond the formal duration of conversion). The vertical axis opposes normative assessments of the effects of conversion to comprehensive studies of conversion as a multidimensional issue (top of Fig. 1).

trajectories (Ruault, 2006). Are they specific to organic farming or integrated into the "ordinary" services so as to facilitate conversions, as in Denmark (Kaltoft, 1999)? What is the role of suppliers or clients (such as cooperatives) or organic certification inspectors (Sepannen and Helenius, 2004)?

Despite their differences, these sociological approaches to conversion all point to an important problem. This is the fact that farmers' motivations are generally analysed after conversion, as if they had not changed after that point in time. Indeed, motivations which are given a few years after conversion might well not be those that would have been expressed at the time of converting. It makes it all the more interesting to study conversion through farmers' trajectories, keeping in mind the idea that time and experience change the interpretation one has of one's own trajectory.

What can we conclude from this examination of agronomical and sociological methodological approaches to conversion? In agronomy, as the focus is generally on the effects of conversion, the motivations are more or less pushed into the background (Fig. 1). When they are taken into account, motivations are considered as answers to technical problems (sanitary problems in livestock farming, a failure in agricultural methods, low yields and difficulties in soil tillage) and economic drawbacks (low livestock productivity due to diseases or the high cost of inputs) (Berthou et al., 1972). Moreover, we have seen that in agronomical approaches, the dynamical and transitional aspects are often underestimated in favour of comparisons of stabilised situations, either between organic and conventional farming, between before and after conversion, or during the conversion period versus a few years later. This weakness of a dynamical approach may seem paradoxical as systemic approaches as well as case studies focused on human activities both entail a teleological vision (Padel, 2002), and because at the farm level conversion often leads to a revision of initial objectives.

On the other hand, sociological studies, which favour the study of the motivations and conceptions of organic farming, often ignore the characteristics of production systems (Morel and Le Guen, 2002), which makes it difficult to analyse spurs and brakes for the development of organic farming. However, some sociological approaches take into consideration better the dynamical and transitional aspects of conversion.

The construction of interdisciplinary approaches of conversion combining agricultural and social sciences might help acknowledge the diversity of initial situations and the diversity of trajectories and help analyse the multiple dimensions of these trajectories. This has been attempted in several recent studies (O’Riordan and Cobb, 2004; Darnhofer et al., op.cit.; Noe and Alroe, 2003; Noe et al., 2005; Flaten and Lien, 2006; Bellon et al., 2007).

\section{CONVERSION AS A TRANSITION MODEL FOR AGRICULTURE}

This examination of agronomical and sociological literature does not only lead to the identification of the different methods used to approach conversion in each field and the promise held by interdisciplinary studies. It also sheds light on the main paradigms of organic farming. Even though they have done it each on their own, agricultural and social sciences have both dealt with the diverse conceptions of organics and the paradigms that sustain these conceptions. Beyond the case of organic farming, these scientific debates offer relevant conceptual tools to approach any and all transitions to sustainable agriculture.

\subsection{Organic farming paradigms: between input substitution and system redesign}

The identification of the main conceptual paradigms of organic farming is central both to social and agronomical scientists, as several studies assess it in different contexts. Based on the case of Denmark, Kaltoft identifies four paradigms: the paradigm of nutrients (or conventional point of view), the paradigm of soil fertility (ecological point of view), the biodynamic paradigm and a paradigm of communication which 
involves aspects of the three others. In the case of the Netherlands, other authors distinguish three conceptions within organic farming: natural as the organic, natural as the ecological and natural as referring to nature as a holistic entity (Verhoog et al., 2003). They relate these concepts to three main approaches to organic agriculture: a no chemicals approach, an agro-ecological approach and an integrity approach. This last one entails a spiritual dimension neighbouring the holistic biodynamic principles. A third study analyses the organic farmers' relations to nature and places them between an anthropocentric pole and a "natural-pragmatic" pole (Tress, 2001). In the first case, productivity is the guideline for farmers' actions and nature has only an instrumental value; farmers aim for a direct control of agricultural production and performances in an unchanged technological frame of reference. In the second case, humans and nature co-exist, nature is recognised as having a certain value and as being an autonomous entity, interactions between techniques and the components of the "agroecosystem" have to be built so as to enhance natural regulation processes and partial or indirect effects.

All these suggestions of distinct categories of organic conceptions can be related to the binary distinction between an "input substitution paradigm" and a "system redesign" paradigm first suggested by biologists (Hill, 1985; Hill and MacRae, 1995; Altieri and Rosset, 1996) and afterwards used by many authors. The first one defines organic farming as the ban of certain inputs and/or the recommendation of others (list of eligible inputs to "fight against" pests and diseases, although with biological methods), whereas the second one defines it through more qualitative and global principles such as crop rotation or means to overcome sanitary problems. This holistic paradigm refers more broadly to the construction of diversified production systems following the ecological model considered as the "natural" one, where interactions between components guarantee fertility, productivity and resilience properties. For Rosset and Altieri (1997), the basic components of sustainable agroecosystems are as follows: (i) reliance on locally available resources and enhancement of positive interactions among plants, animals and soils, (ii) organic matter management and nutrient cycling, (iii) maintenance of vegetative cover with reduced tillage, cover crops and mulches, and (iv) habitat management favouring natural pest regulation. In the perspective of a transition towards a more sustainable agriculture, the authors (Hill and MacRae, 1995; Rosset and Altieri, 1997) differentiate three approaches: increased efficiency of input use, input substitution or the replacement of agrochemical inputs by environmentally more benign inputs (e.g. botanical or microbial insecticides), and system "redesign" arising from the transformation of agroecosystem functions and structure. According to them, the prevalence of input substitution drastically limits the potential solutions to the socio-economic and ecological crisis of modern agriculture, in the sense that this substitution does not call into question monoculture or the dependency on external inputs. The transition of a farm inside organic agriculture, once converted, could be defined through these three paradigms considered as successive steps. Indeed, by definition, organic agriculture relies on an input substitution. Once this substitu- tion is accomplished, it is possible to aim for a better efficiency of inputs inside the organic framework, or to go even further and to aim for a "redesign".

Does this notion of redesign also reflect the parallel evolution of farm and landscape structures? Organic farms are supposed to be diversified and this diversification is to be seen in landscape changes. Conversion can then be considered as a case study to test land-use options and crop combinations.

Several studies conducted in Denmark shed light on this aspect. Langer used a database composed of 448 conversion projects in which farmers describe their situations and their projects regarding crops and livestock production (Langer, 2002). Over a 4-year period, no tangible evolution was perceived in production orientations. The regional distribution of cropping systems would therefore not be strongly modified in the short term. Conversely, land-use patterns change with conversion: a $20 \%$ decrease in the acreage for cereal production, a doubling of the acreage for grassland in rotation, a decrease in acreages for set-aside, row crops and oilseed rape. However, these farmers' intentions have not been verified through monitoring after conversion.

In addition, Levin studied the consequences of conversion on landscape composition (Levin, 2007), based on four components as suggested by Kuiper (2000): density of uncultivated landscape elements, diversity of land uses per unit area and mean field size. The study relies both on national agricultural surveys and on regional analyses and photo-interpretations. The national analysis shows a greater diversity of soil uses and a smaller size of plots in organic farms. Conversion to organic farming lowers or inverses the general trend towards an increase in farm size. However, the regional analysis does not reveal any direct relation between organic agriculture and noncultivated landscape elements on this scale. This could be due to the absence, in organic standards, of specific rules concerning the farm integration of the functionalities of woodlands or ecological infrastructures, which differs from other specifications such as integrated production (Girardin and Sardet, 2003).

Economists (Lampkin and Padel, 1994) as well as sociologists and geographers have also discussed this distinction between substitution and redesign. We find this reflects the ability of such paradigms to circulate as well as bring diverse disciplines to the same table. Studies from an interdisciplinary point of view might well offer the most promising conclusions.

From the analysis of comprehensive interviews with 150 farmers, the geographer Guthman (2000) used methods based on indicators elaborated by biotechnical sciences (Van der Werf and Petit, 2002), so as to classify the farmers according to their degree of adoption of agro-ecological principles (Altieri, 1995), and to the dynamics of conventionalisation. The analysis, which looks both at the differences between organic farmers and at the gaps between agro-ecological principles and farmers' practices, leads to a double distinction:

- between mixed farmers who partially converted to organic farming and restrict themselves to following the rules which they interpret in terms of input substitution, and farmers who fully converted; as well as 
- between large farms and smaller farms. The large farms depend more on external inputs, whereas the small ones rely on compost-making and intercropping.

However, few producers really approximate an agroecological ideal integrating crops and livestock, companion crops, and/or an intense mosaïc of cropping design combined with a high degree of on-farm input development. As for pest and disease management, the methods used range from proactive prophylactic measures and habitat maintenance enhancing beneficial insects to an organic agriculture " by default", without an explicit strategy to manage or by-pass biotechnical issues (apart from using eligible inputs). In between these polarities, a "wait and see" behaviour can be identified, quite similar to an IPM-based strategy.

This distinction between the two paradigms of input substitution and system redesign converges with the distinction identified in the conventionalisation debate between two distinct trends in organics, opposing industrial farmers and farmers involved in a more ideological and agro-ecological vision of organic farming. The concept of "conventionalisation" was developed by political food economists in a founding article in 1997 (Buck et al., 1997). According to them, organic production and markets were being overcome by large-scale structures and were becoming more and more vertically integrated, just like in conventional agriculture. Conventionalisation is characterised by the concentration of capital among fewer and larger growers and intermediaries more equipped to deal with retailers, the erosion of organic standards, the generalisation of the substitution of allowable inputs for proscribed inputs, and a growing dependence of farmers on input suppliers and supermarkets. This evolution led to a bifurcation into two distinct trends: a main conventionalised one and a minor resistant one.

This conventionalisation thesis was developed and is still debated over California, where large-scale growers and monoculture are prevalent. In the UK, the growth of the organic sector has also generated a decline in farm gate prices and in farmers' income which has called into question the sustainability of current levels of organic production (Smith et Marsden, 2004). This phenomenon is due to the conjunction of privatesector initiatives (consumption-orientated) and government incentives to increase conversion (production-orientated), which lead the authors to highlight the limits of government intervention when it only deals with production and neglects the downstream supply chains. Other studies in other areas such as Australia (Lockie and Halpin, 2005), Canada (Hall and Mogyorody, 2001) and southern countries (Halberg, 2007) show that more diverse evolutions should be acknowledged. If the conventionalisation thesis reveals how the boundaries between conventional and organic agricultures might be contested and mobile (Goodman, 2000), it is therefore commonly agreed that the analyses have to be clearly related to their specific geographical context.

Several authors (Langer and Frederiksen, 2005; Darnhofer, 2006) estimate that conventionalisation goes hand in hand with an increasing dependency on external inputs (equipment, fertilisers and animal feed) and with a substitution of work by capital. These tendencies towards a bipolarisation are also visible in the construction of rules (Goodman, 2000), as the organic label, according to some authors, reduces the natural-social complexity of organics to a simple question of inputs (Allen and Kovach, 2000). For others, it is more largely the impact of the conditions imposed by the process of agro-industrialisation which impedes real "alternative" farming practices (Guthman, 2004). A few recent studies focus on the phenomenon of "de-conversion" or "reversion", which they relate to this conventionalisation trend (Campbell et al., 2006; Kaltoft and Risgaard, 2006).

From the point of view of environmental sociology, this distinction of these two paradigms could lead to asking if organic farming is more a phenomenon of ecological modernisation (Spaargaren, 1997) or of ecologisation of agriculture (Deverre, 2004; Obach, 2007). In Brazil, Caporal and Costabeber studied the transition toward an agro-ecological model and its implementation, which might proceed through different paths and steps (Caporal and Costabeber, 2004). This model is presented in sharp opposition to the industrialisation of agriculture and to the green revolution, but also to certain forms of traditional agriculture. For these authors, the choice of such an agro-ecological model is far from being only an answer to a market which demands a greening of food products through a green intensification: it involves environmental values and new ethics in terms of man-nature relations (Brandenburg, 2002).

Therefore, the two paradigms of input substitution and system redesign not only correspond to specific types of relations to techniques and market, but can also be compared with the two notions of ecological modernisation and ecologisation in environmental sociology (Table II). The input substitution paradigm remains in the technical framework of conventional agriculture, in which agricultural performances rely on a notion of control over natural phenomena and irregularities. Regarding crop protection, the central idea is still to fight against pests even if more ecological means such as biological control are necessary, whereas the system redesign paradigm highlights natural regulation processes and partial or indirect effects.

These two paradigms also differ in terms of temporalities and means devoted to conversion. Input substitution is nearer to the administrative time of conversion (with a possibility of reversion in the case of technical failure or economic difficulties), whereas the systemic conception supposes a more lasting commitment. Finally, the two paradigms differ regarding the role of extension services and certification bodies. Indeed, compliance with the first paradigm can be controlled through ordinary inspection procedures such as check-lists, at the cost of a more comprehensive approach: it is easier to inspect input purchases than the farming system as a whole.

\subsection{The case of organic farming as an indicator of society questioning agriculture and food models}

If social sciences take an increasing part in this debate around the paradigms sustaining the conceptions and practices of organic farming, their specific contribution also involves the 
Table II. Two main paradigms of organic farming and their consequences in terms of development.

\begin{tabular}{|c|c|c|c|}
\hline $\begin{array}{l}\text { The two paradigms of organic } \\
\text { farming }\end{array}$ & $\begin{array}{l}\text { Corresponding concept in } \\
\text { Environmental sociology }\end{array}$ & Relation to techniques & Market trends \\
\hline Input substitution paradigm & Ecological modernisation & $\begin{array}{l}\text { Direct control of the agricultural production through } \\
\text { techniques, in an unchanged reference frame }\end{array}$ & $\begin{array}{l}\text { Conventionalisation and } \\
\text { Greening of food products }\end{array}$ \\
\hline System redesign paradigm & Ecologisation & $\begin{array}{l}\text { Construction of interactions between agricultural } \\
\text { techniques and ecosystem components }\end{array}$ & $\begin{array}{l}\text { Recomposition of marketing } \\
\text { towards shorter circuits }\end{array}$ \\
\hline
\end{tabular}

impact of the organic movement on civil society and the links to a broader debate over the future of agriculture and food systems.

The role of the organic movement is surely different today than in its beginnings, when the mission of agriculture was to feed the nations and when productivism was therefore legitimate, with hardly any place for social criticism and movements in agricultural decisions (Michelsen, 2001; MacMahon, 2005). In the French case, it seems that organic pioneers failed to create a real social movement that would have brought together producers and consumers (Piriou, op.cit.). According to this author, farmers followed the logic of their corporatist lobby and could not go beyond the boundaries of their profession. About 20 years ago, however, from the analysis of the studies of organic farming carried out in the 1970s and 1980s, Barrès et al. identified a progressive shift towards a willingness to be accepted and approved by society and to develop links between cities and the countryside (Barrès et al., op.cit.). However, it is only quite recently that an alliance between producers and consumers really began to visibly take shape, even though the importance of pioneering signs and experiences such as organic cooperative networks has to be recognised.

Today, organic networks greatly contribute to getting the civil society involved in debates over agriculture and food. However, certain authors denounce a repression of the movement's ideological content and a betrayal of organics' initial ideals through which the dominating definition of organic agriculture reduces relations to nature to a question of allowed inputs. Both the institutionalisation and the conventionalisation of organics go hand in hand with a decline in its idealistic vision and a decline in farmers' environmental concerns (Tovey, 1997; Kaltoft, 1999). Many authors, though, have a more optimistic vision of the possible place of organics in political and social change. This place would rely on the capacity of organics to transform the way people look at their food, in particular through unveiling the conditions of production, instead of hiding them. Alternative networks invite consumers to consider products through the way they are grown, the kind of labour involved, the relationship to nature or even the public research investments which are implied in this production, and not only through the material characteristics of products. Thus organics could be an answer among others to larger concerns about the rising centralised control of society's relations with agricultural nature (Allen and Kovach, 2000; Goodman, 2000).

These suggestions imply bridging the classical gap between production and consumption. The evolution of organics relies on the conversion of both farmers to organic farming and consumers to organic food. Indeed, organic consumption is an area of research that was investigated by economic and marketing science (Sylvander, 1997; Codron et al., 2006; Holt, 2006) as well as by sociology and anthropology (Ouedraogo, 1998; César, 1999). The specificity of more recent studies in social sciences is that they tackle the interactions between production and consumption, that had received little attention (Lockie et al., 2000, Tovey, 2002). Many authors shed light on these links between production and consumption through the analysis of some recent developments in agro-food systems, and specifically the study of alternative food networks centred on organic but also local production (Murdoch and Miele, 1999; Marsden, 2000; Goodman, 2002, 2003; Goodman and DuPuis, 2002; Guthman, 2002; Lamine, 2005; Moore, 2006). The capacity of organics to have a larger impact on the visions and evolutions of agro-food systems also relies on the idea that consumption could be considered as a possible form of political action. This has already been suggested by several authors focusing on alternative food systems, as seen before, as well as on reflexive consumption (DuPuis, 2000).

\subsection{Beyond disciplinary divisions: the study of transitions in agriculture}

Today, it is becoming more and more evident that it is necessary to explore and develop intermediary forms between a conventional agriculture whose productivism appears to be socially and environmentally unsustainable and an organic agriculture that is not suitable for every soil, region and farmer. In this context, the two paradigms of input substitution and system redesign, that were identified on the base of organic studies, might help enrich and frame the discussion over future agricultural models. Beyond organic farming, many studies use these paradigms so as to analyse the transformations of agriculture.

In the Brazilian state of Rio Grande do Sul, these paradigms help to classify all farmers into three categories: conventional farmers (who reduce their use of chemical input for economic reasons), farmers in transition (who substitute chemical inputs with biological ones), and farmers in a "redesign" type of transition (who adopt an ecological and systemic approach incorporating soil ecological management, crop rotation and diversification, mixed crop-livestock integration, reforestation and management of agro-forestry systems) (Caporal and Costabeber, op. cit.). According to certain authors, integrated production also corresponds to a mid-term and fluid transition between conventional and organic agricultures (Niggli, 1999), with strategies such as integrated protection (IPM), reasoned 
crop fertilisation and priorisation of biological control methods (Hodges, 1981).

Taking into account the complexity of transitions in agriculture supposes going beyond a restricted agronomical vision that would ignore the social aspects linked to food systems as well as the natural phenomena such as climate change. This is what some authors try to do by defining agro-ecology broadly as an ecology of food systems (Francis et al., 2003), based on the notions of ecosystem (Lowrance et al., 1984) and agroecosystem (Gliessman, 1990), and which can be opposed to a vision of agro-ecology as an ecology applied to agricultural production (Altieri, 1983). Interdisciplinarity is considered by these authors as a prerequisite to the development of agroecology, as economic and social aspects have to be included (Altieri, 1989; Dalgaard et al., 2003).

Interdisciplinary approaches are more generally of great interest when considering conversion to organic farming as an exemplary case of larger transitions in agriculture, as they allow the taking into consideration of these transitions by surpassing their sole technical aspects, and by paying attention to their temporal dimension. With this perspective in mind, approaching conversion to organic farming from the crossroads of several different disciplines holds promise.

To cross history with agronomy would allow an analysis over time of the transformation of the historical paradigms of agronomy, which can be identified as successively chemical, physical, biological and finally, ecological paradigms (Robin and Aeschlimann, 2007). Specifically for organic agriculture, a historical approach can help to identify the founding paradigms and their differences, mainly between Steiner's organic vision of a farm integrating breeding as a key component, and Howard's vision favouring soil fertility and humus management. This leads to renouncing the idea of a unique original paradigm for organic farming and contributes to the necessary acknowledgement of organics' internal diversity (Besson, 2007).

Collaboration between agronomy and sociology allows the study of the transformations of farmers' practices over time. The notion of a trajectory allows the consideration of conversion over a longer time period and from a wider point of view than in its official definition. Organic farmers' trajectories encompass at the same time technical trajectories, social trajectories, learning trajectories and network trajectories Bellon et al., op.cit. Compared with classical typological methods, such studies, involving agronomists and social scientists, prove that interdisciplinary approaches are more adequate to reflect the actual diversity of organic farming, as well as the evolutionary potential of farming systems and the transitional nature of conversion trajectories. In these socio-technical trajectories, the questions of plant protection practices, of input use and of farmers' representations of these issues, are central. It may seem paradoxical to note that these questions are not often raised in studies of organic farming, maybe because these problems are supposed to be solved, whereas they are more often central to comparative studies of conventional and organic farming. Pesticides have been proved to be not only a crop protection means but also a way to maintain a visible standard (Fairweather, 1999), in the sense that conventional farmers are often proud to have clean fields, which is acknowledged as a major bottleneck regarding the adoption of low-input practices.

The study of organic farming as an innovation is of prime interest when thinking more generally about the transitions towards more sustainable agricultures. Some authors have applied to the case of organic farming the classical theories of adoption and diffusion, which identify innovators, as well as early and late adopters throughout the diffusion of any innovation (Padel, 2001). As organic farmers do not always come from an agricultural background and are often linked to scientists and/or environmental and consumer movements, other types of innovation than classical top-down processes can be expected (Michelsen, 2001). The construction of knowledge and the co-production of innovations is still a quite unexplored area of research (Gibbons et al., 1994), even though there are pioneering works which it might be useful to go back to (Salmona, 1994).

Finally, interactions between agricultural and social sciences are necessary to enlarge the scope from agriculture to food chains, and thereby consider the sustainability of organic agriculture or any other form of agriculture (Stassart and Jamar, 2005). Other authors also suggest considering the different development models of organic agriculture. Sylvander et al. (2006) propose to identify these development models through two axes, the first one opposing individual logics to collective organisation forms linked to markets and territories, the second one opposing the mere compliance with organic rules to a re-conception of systems.

\section{CONCLUSIONS}

This review of agronomical and sociological literature available in the English- and French-speaking worlds, with some incursions into other social sciences, reveals that conversion, far from being limited to an administrative period with its codified phases, is a multidimensional subject. Conversion can be considered as a programme whose temporalities vary from two years to a farmer's generation. This approach would ensure the achievement of the dynamic equilibrium necessary to establish an ecological basis for sustainability. Beyond the biotechnical aspects of production, conversion supposes transformations in farmers' marketing strategies as well as in their representations, values and links to various social networks. Therefore, the study of conversion invites new definition of research topics, i.e., to switch from the plot scale to the farm or even the landscape scale, from production to food chains and food systems, from the notion of changes in the cropping system to the notion of trajectories along which the relations to techniques, nature, territory, markets and consumers are redefined. From this point of view, the decisive contribution of social sciences is to suggest methods that go beyond the administrative and individual conversion and focus on processes, temporalities and networks.

Crossing over disciplinary boundaries has allowed us to identify a series of oppositions which structure the debates on organics and relations to techniques and market according 
to two paradigms of input substitution and system redesign, which can, respectively, be compared with the two notions of ecological modernisation and ecologisation in environmental sociology. The input substitution paradigm remains in the framework of conventional agriculture, based on the notion of control over natural phenomena and irregularities, whereas the system redesign paradigm relies on natural regulation processes and partial or indirect effects. Beyond organic farming, these paradigms prove useful to consider changes towards more sustainable agricultural practices, especially in terms of plant protection.

Indeed, conversion to organic farming is an exemplary and well-informed case to think more broadly about changes in agricultural systems. This entails approaching conversion as a more general figure of transition of agriculture (Sangar and Abrol, 2004), from a perspective which can refer to the notions of agro-ecology (Gliessman, 1997) and sustainability (Kates et al., 2001; Rigby and Cáceres, 2001; Elzen and Wieczorek, 2005). Such a perspective should be based on the development of fruitful interactions between agricultural and social sciences so as to encompass the aspects of consumption, markets, public policy and the conceptions and practices of agriculture and nature. This ambition raises further questions such as the capacity of organic farming to "feed the world" in the case of conversion of large areas (Griffon, 2006; FAO, 2007) as well as several subjects quite ignored in the literature, such as questions concerning the place of women in organic farming, developed only in rare studies (Barrès et al., 1985; Chiappe and Flora, 1998); work organisation and relationships; and social justice from the production and consumption side, with a focus on fair access to healthy food (Goodman, 2000).

Acknowledgements: The authors warmly thank the 2 anonymous reviewers as well as T. Doré for his extensive reading and relevant comments, C. Deverre, E. Noe and H. Alroe for their suggestions and G. Holt for her contribution to extending our database.

\section{REFERENCES}

Allard G., David C., Henning J. (2001) La spécialisation des systèmes céréaliers en Europe: origine et conséquences, in: L'agriculture biologique face à son développement : les enjeux futurs, Lyon, 1999/12/6-8.

Allen P., Kovach M. (2000) The capitalist composition of organic: The potential of markets in fulfilling the promise of organic agriculture, Agr. Human Values 17, 221-232.

Alroe H., Kristensen E.S. (2002) Towards a systemic research methodology in agriculture, Rethinking the role of values in science, Agr. Human Values 19, 3-23.

Alroe H. (2005) What makes organic agriculture move - autopoiesis, protest or market? A polyocular approach, in: ESRS XXI Congress, Keszthely, Hungary, 2005/08/22-26.

Altieri M. (1989) Agroecology: A new research and development paradigm for world agriculture, Agr. Ecosyst. Environ. 27, 37-46.

Altieri M. (1995) Agroecology: the science of sustainable agriculture, Westview Press.

Altieri M., Rosset P. (1996) Agroecology and the conversion of largescale conventional systems to sustainable management, Int. J. Env. Studies 50, 165-185.
Altieri M.A. (1983) Agroecology: The scientific basis of alternative agriculture, Division of Biological Control, University of California, Berkeley.

Andersen A., Eltun R. (2000) Long-term developments in the carabid and staphylinid (Col., Carabidae and Staphylinidae) fauna during conversion from conventional to biological farming, J. Appl. Entomol. $124,51-56$.

Barrès D., Bonny S., Le Pape Y., Rémy J. (1985) Une éthique de la pratique agricole. Agriculteurs biologiques du Nord-Drôme, Paris, Grignon, Grenoble, INRA-ESR.

Bellon S., Tranchant J.-P. (1981) Elements of analysis of biological husbandry on four farms in South-East France, in: Stonehouse B. (Ed.), Biological Husbandry: a scientific approach to organic farming, Butterworths, London, UK, pp. 319-326.

Bellon S., Mondain-Monval J.-F., Pillot D. (1985) RechercheDéveloppement et Farming System Research : à la quête de l'opérationnalité, in: Colloque Systèmes de production agricole caribéens et alternatives de développement, Martinique.

Bellon S., Perrot N., Navarrete M., Fauriel J., Lamine C. (2007) Converting to organic horticulture as socio-technical trajectories, in: XXII ESRS Congress, Wageningen, Netherlands, 2007/08/2024.

Bengtsson H., Öborn I., Jonsson S., Nilsson I., Andersson A. (2003) Field balances of some mineral nutrients and trace elements in organic and conventional dairy farming-a case study at Öjebyn, Sweden, Eur. J. Agron. 20, 101-116.

Bengtsson J., Ahnström J., Weibull A.C. (2005) The effects of organic agriculture on biodiversity and abundance: a meta-analysis, J. Appl. Ecol. 42, 261-269.

Benoît M., Tournadre H., Dulphy J.-P., Cabaret J., Prache S. (2005) Conversion of a lamb production system to organic farming: how to manage, for what results? in: International Scientific Conference on Organic Agriculture, Researching Sustainable Systems, 2005/9/2123, Adelaide, Australia.

Benoît M., Veysset P. (2003) Conversion of Cattle and Sheep Suckler Farming to Organic Farming: Adaptation of the Farming System and Its Economic Consequences, Livest. Prod. Sci. 80, 141-152.

Berthou Y., Capillon A., Cordonnier J., Roumain de la Touche Y. (1972) L'agriculture biologique : éléments de diagnostic à partir d'une enquête sur 40 exploitations, Ronéo INA Paris-Grignon, 88 p.

Bertsen J., Grant R., Olesen J.E., Kristensen I.S., Vinter F.P., Møllgaard J.P., Petersen B.M. (2006) Nitrogen cycling in organic farming systems with rotational grass-clover and arable crops, Soil Use Manage. 22, 197-208.

Besson Y. (2007) Histoire de l'agriculture biologique: une introduction aux fondateurs, Sir Albert Howard, Rudolf Steiner, Hans Peter Rusch, Masanobu Fukuoka, Université de Technologie de Troyes, CREIDD. Ph.D.

Best H. (2005) Organic farmers in western Germany: is there a decline in environmental concern? in: ESRS XXI Congress, Keszthely, Hungary, 2005/08/22-26.

Blanchart E., Cabidoche Y.-M., Gautronneau Y., Moreau R. (2005) Les aspects spatiaux et environnementaux de l'agriculture biologique, in: François M., Moreau R., Sylvander B. (Eds.), Agriculture biologique en Martinique, Quelles perspectives de développement? IRD Éditions, pp. 325-379.

Bonnaud T., Leseigneur A., Soulard C.-T. (2000) Situer le profil des agriculteurs en conversion et leurs attentes. Une étude de cas en Bourgogne, Travaux et Innovations 65, 19-23

Bonneuil C. (2004) Quelle politique scientifique pour entrer dans le 21e siècle ? Vars un nouveau contrat entre recherche et société. Contribution de la Fondation sciences Citoyennes aux États-Généraux sur l'avenir de la Rechereche. Note 
$\mathrm{n}^{\circ} 2$ de la Fondation Sciences Citoyennes. oct. 2004, http://sciencescitoyennes.org/spip.php?article1440.

Brandenburg A. (2002) Movimento agroecologico: trajetória, contradições e perspectivas, Revista Desenvolvimento e Meio Ambiente (Ed UFPR) 6.

Buck D., Getz C., Guthman J. (1997) From Farm to Table: The Organic Vegetable Commodity Chain of Northern California, Sociologia Ruralis 37, 3-20.

Bulson H.A., Welsh J.P., Stopes C.E., Woodward L. (1996) Agronomic viability and potential economic performance of three organic four year rotations without livestock, Aspects Appl. Biol. 47, 277-286.

Cabaret J., Mage C., bOUILHOL m. (2002) Helminth intensity and diversity in organic meat sheep farms in centre of France, Vet. Parasitol. $105,33-47$

Cadiou O., Lefebvre A., Le Pape Y., Mathieu-Gaudrot F., Oriol S. (1975) L'agriculture biologique en France : écologie ou mythologie, Presses Universitaires, Grenoble France, 179 p.

Campbell H., McLeod C., Rosin C. (2006) Auditing sustainability: the Impact of Eurep GAP in New Zealand, in: Holt G.C., Reed M. (Eds.), Sociological perspectives of organic agriculture, Cab International, pp. 157-173.

Caporal F.R., Costabeber J.A. (2004) Agroecologia e Extensão Rural: contribuições para a promoção do desenvolvimento rural sustentãvel, MDA/SAF/DATER-IICA, Brasilia.

Caporali F., Mancinelli R., Campiglia E. (2003) Indicators of Cropping Systems Diversity in Organic and Conventional Farms in Central Italy, Int. J. Agr. Sustain. 1, 67-72.

César C. (1999) De la conception du naturel, les catégories à l'œuvre chez les consommateurs de produits biologiques, Thèse de sociologie, Paris X.

Chiappe M., Flora C. (1998) Gendered Elements of the Alternative Agriculture Paradigm, Rural Sociology 63, 372-393.

Codron J., Siriex L., Reardon T. (2006) Social and environmental attributes of food products in an emerging mass market: Challenges of signaling and consumer perception, with European illustrations, Agr. Human Values 23, 283-297.

Coquil X., Fiorelli J.-L., Bazard C., Foissy D., Trommenschlager J.-M., Blouet A. (2006) Prototyping organic mixed crop-dairy systems at a local scale: a multi-attribute approach, in: Eur. Joint Organic Congress Organic Farming and Eur. Rural Development, Odense (DK), 2006/5/30-31.

Dabbert S., Madden P. (1986) The transition to organic agriculture: a multi-year simulation model of a Pennsylvania farm, Am. J. Alternative Agr. 1, 99-107.

Dalgaard T., Heidmann T., Mogensen L. (2001) Potential N-losses in three scenarios for conversion to organic farming in a local area of Denmark, Eur. J. Agron. 16, 207-217.

Dalgaard T., Hutchings N., Porter J. (2003) Agroecology, scaling and interdisciplinarity, Agr. Ecosyst. Environ. 100, 39-51.

Darnhofer I., Schneeberger W., Freyer B. (2005) Converting or not converting to organic farming in Austria: Farmer types and their rationale, Agr. Human Values 22, 39-52.

Darnhofer I. (2006) Organic farming between professionalisation and conventionalisation - The need for a more discerning view of farmer practices, in: Eur. Joint Organic Congress Organic Farming and Eur. Rural Development, Odense (DK), 2006/5/30-31.

David C. (1999) Research in arable farming systems in Europe. Acquired and new stakes., in: Research Methodologies in Organic Farming, Frick, Switzerland, 30 September-3 October 1998.

Deverre C. (2004) Les nouveaux liens sociaux au territoire, Nat. Sci. Soc. $12,172-178$.
DuPuis E.M. (2000) Not in my body: BGH and the rise of organic milk, Agr. Human Values 17, 285-295.

Elliot S.L., Mumford J.D. (2002) Organic, integrated and conventional apple production: why not consider the middle ground? Crop Prot. 21, 427-429.

Elzen B., Wieczorek A. (2005) Transitions towards sustainability through system innovation, Technol. Forecasting Social Change 72, 651661.

Eriksen J., Thorup-Kristensen K. (2002) The effect of catch crops on sulphate leaching and availability of $\mathrm{S}$ in the succeeding crop on sandy loam soil in Denmark, Agr. Ecosyst. Environ. 90, 247-254.

Fairweather J. (1999) Understanding how farmers choose between organic and conventional production: Results from New Zealand and policy implications, Agr. Human Values 16, 51-63.

FAO (2007) Report. International Conference on Organic Agriculture and Food Security, Rome, 3-5 May 2007, 11 p., ftp://ftp.fao.org/docrep/fao/meeting/012/J9918E.pdf.

Flaten O., Lien G. (2006) Organic dairy farming in Norway in relation to the conventionalisation debate, in: Eur. Joint Organic Congress Organic Farming and Eur. Rural Development, Odense (DK), 2006/5/30-31.

Flessa H., Ruser R., Dörsch P., Kamp T., Jimenez M.A., Munch J.C., Beese F. (2002) Integrated evaluation of greenhouse gas emissions $\left(\mathrm{CO}_{2}, \mathrm{CH}_{4}, \mathrm{~N}_{2} \mathrm{O}\right)$ from two farming systems in southern Germany, Agr. Ecosyst. Environ. 91, 175-189.

Francis C., Lieblein G., Gliessman S., Breland T., Creamer N., Harwood R., Salomonsson L., Helenius J., Rickerl D., Salvador R. (2003) Agroecology: The ecology of food systems, J. Sustain. Agr. 22, 99118.

Gautronneau Y., Godard D., Le Pape Y., Sebillotte M., Bardet C., Bellon S., Hocdé H. (1981) Une nouvelle approche de l'Agriculture Biologique, Economie Rurale 142, 39.

Gibbons M., Limoges C., Nowotny H., Schwartzman S., Scott P., Trow M. (1994) The New Production of Knowledge: the Dynamics of Science and Research in Contemporary Societies, London, Sage.

Gigleux C., Garcin A. (2005) L'arboriculture biologique, État des lieux de la conversion, Paris, CTIFL.

Girardin P., Sardet E. (2003) Environmental assessment of specifications for arable farms, in: Conference on ecolabels and greening of food market, Boston, USA, 2002/11/7-9.

Gladwin C.H. (1989) Indigenous Knowledge Systems, The Cognitive Revolution, and Agricultural Decision Making, Agr. Human Values 6, 32-41.

Gliessman S. (1990) Agroecology: researching the ecological basis for sustainable agriculture, Ecol. Studies 78, 3-10.

Gliessman S. (1997) Agroecology: ecological processes in agriculture, Ann Arbor Press, Michigan.

Goodman D. (2000) The changing bio-politics of the organic: Production, regulation, consumption, Agr. Human Values 17, 211-213.

Goodman D. (2002) Rethinking food production-consumption: integrative perspectives, Sociologia Ruralis 42, 271-277.

Goodman D. (2003) The quality 'turn' and alternative food practices: reflections and agenda, J. Rural Studies 19, 1-7.

Goodman D., DuPuis E.M. (2002) Knowing food and growing food: beyond the production-consumption debate in the sociology of agriculture, Sociologia Ruralis 42, 5-22.

Grandy A.S., Robertson G.P. (2007) Land-Use Intensity Effects on Soil Organic Carbon Accumulation Rates and Mechanisms, Ecosyst. 10, $59-74$

Griffon M. (2006) Nourrir la Planète, Paris, Odile Jacob.

Guthman J. (2000) An agro-ecological assessment of grower practices in California, Agr. Human Values 17, 257-266. 
Guthman J. (2002) Commodified meanings, meaningful commodities: rethinking production-consumption links through the organic system of provision, Sociologia Ruralis 42, 295-311.

Guthman J. (2004) The Trouble with Organic Lite in California. A Rejoinder to the Conventionalisation Debate, Sociologia Ruralis 44, 301-316.

Halberg N. (2007) The Impact of Organic Farming on Food Security in a Regional and Global Perspective: Challenges and Prospects, Issues paper presented during the conference "Organic Agriculture and Food Security", 3-5 May 2007, FAO, Rome, Italy.

Hall A., Mogyorody V. (2001) Organic farmers in Ontario: an examination of the conventionalization argument, Sociologia Ruralis 41, 399-422.

Hansen B., Fjelsted H., Kristensen E.S. (2001) Approaches to assess the environmental impact of organic farming with particular regard to Denmark, Agr. Ecosyst. Environ. 83, 11-26.

Hansen B., Kristensen E.S., Grant R., Høgh-Jensen H., Simmelsgaard S.E., Olesen J.E. (2000) Nitrogen leaching from conventional versus organic farming systems - a systems modelling approach, Eur. J. Agron. 13, 65-82.

Harris C.K., Powers S.E., Buttel F.H. (1979) Myth and reality in organic farming: a profile of conventional and organic farmers in Michigan., in: Paper presented at the Annual Meeting of the Rural Sociology Society, Burlington, Vermont, August 1979.

Harwood R.R. (1990) A history of sustainable agriculture, in: Edwards C.A. et al. (Eds.), Sustainable Agricultural Systems, St. Lucie Press, Florida, pp. 3-19.

Hill S.B. (1985) Redesigning the food system for sustainabilty, Alternatives 12, pp. 32-36.

Hill S.B., MacRae R. (1995) Conceptual frameworks for the transition from conventional to sustainable agriculture, J. Sustain. Agr. 7, 8187.

Hodges R. (1981) An agriculture for the future, in: Stonehouse B. (Ed.), Biological Husbandry A scientific approach to organic farming, Butterworths, London, pp. 1-14.

Hole D.G., Perkins A.J., Wilson J.D., Alexander I.H., Grice P.V., Evans A.D. (2005) Does organic farming benefit biodiversity? Biol Conserv. 122, 113-130.

Holt G.C. (2006) A conceptual model of willingness to pay for organic food in the UK, in: Holt G.C., Reed M. (Eds.), Sociological perspectives of organic agriculture, Cab International, pp. 88-106.

Holt G.C., Reed M. (Eds.) (2006) Sociological perspectives of organic agriculture, $\mathrm{Cab}$ International.

Hovi M., Garcia Trujillo R.E. (2000) Diversity of livestock systems and definition of animal welfare, in: Second NAHWOA Workshop, Cordoba.

Huxham S., Wilson P., Sparkes D. (2004) Economic analysis of conversion strategies for stockless organic production, Biol. Agric. Hortic. $22,289-303$

Hyvönen T. (2007) Can conversion to organic farming restore the species composition of arable weed communities? Biol. Conserv. 137, 382 390.

Kaltoft P. (1999) Values about Nature in Organic Farming Practice and Knowledge, Sociologia Ruralis 39, 39-53.

Kaltoft P., Risgaard M. (2006) Has organic farming modernized itself out of business? Reverting to conventional methods in Denmark, in: Holt G.C., Reed M. (Eds.), Sociological perspectives of organic agriculture, pp. 126-141.

Kates R.W., Clark W.C., Corell R., Hall J.M., Jaeger C.C., Lowe I., McCarthy J.J., Schellnhuber H.J., Bolin B., Dickson N.M., Faucheux S., Gallopin G.C., Grubler A., Huntley B., Jager J., Jodha N.S., Kasperson R.E., Mabogunje A., Matson P., Mooney
H., Moore III B., O'Riordan T., Svedlin U. (2001) Environment and Development: Sustainability Science, Science 292(5517), 641-642.

Kirchman H., Ryan M.H. (2004) Nutrients in organic farming - are there advantages from the exclusive use of organic manures and untreated minerals? in: 4th Int. Crop Science Congress. "New directions for a diverse planet", Brisbane, Australia, 26 Sept. 1 Oct.

Koesling M., Ebbesvik M., Lien G., Flaten O., Valle P.S. (2005) Motives and potential for conversion to organic farming in Norway, in: XXI ESRS Congress, Keszthely, Hungary, 2005/08/22-26.

Kristiansen P. (2006) Overview of organic agriculture, in: Kristiansen A.T.P., Reganold J. (Eds.), Organic Agriculture, A global perspective, CSIRO Publishing, pp. 1-23.

Kuiper J. (2000) A checklist approach to evaluate the contribution of organic farms to landscape quality, Agr. Ecosyst. Environ. 77, 143156.

Lamine C. (2005) Settling the shared uncertainties: local partnerships between producers and consumers, Sociologia Ruralis 45, 324-345.

Lampkin N. (1986) A research concept for investigating organic farming systems: Case studies, in: Global perspectives on agroecology and sustainable agrycultural systems, Proceeding of the 6th international scientific conference of IFOAM, Santa Cruz, California, USA.

Lampkin N., Padel S. (1994) The Economics of Organic Farming: An International Perspective, CAB International.

Lampkin N., Stolze M. (2006) European Action Plan for Organic Food and Farming, Law, Sci. Policy 3, 59-73.

Langer V. (2002) Changes in farm structure following conversion to organic farming in Denmark, Am. J. Alternative Agr. 72, 75-81.

Langer V., Frederiksen P. (2005) The development of farm size on Danish organic farms - a comment to the conventionalisation debate, in: Int. Scientific Conference on Organic Agriculture: Researching Sustainable Systems, Adelaide, Australia.

Le Pape Y., Rémy J. (1988) Agriculture biologique: unité et diversité, in: Jollivet M. (Ed.), Pour une agriculture diversifiée, Collection Alternatives Rurales, Éditions L'Harmattan, Paris, pp. 134-140.

Levin G. (2007) Relationships between Danish organic farming and landscape composition, Agric. Ecosyst. Environ. 120, 330-334.

Liebhardt W.C., Andrews R.W., Culik M.N., Harwood R.R., Janke R.R., Radke J.K., Rieger-Schwartz S.L. (1989) Crop production during conversion from conventional to low-input methods, Agron. J. 81, $150-159$.

Lockeretz W. (1981) Organic field crop production in the Midwestern Unites States, in: Stonehouse B. (Ed.), Biological Husbandry: a scientific approach to organic farming, Butterworths, London, UK.

Lockeretz W. (1985) US organic farming: What we can and cannot learn from on-farm research, in: Edens T.C. et al. (Eds.), Sustainable agriculture and integrated farming systems, Michigan State University Press, East Lansing, pp. 96-104.

Lockeretz W. (1987) Establishing the proper role for on-farm research, Am. J. Alternative Agr. 2, 132-136.

Lockeretz W., Stopes C. (1999) Issues in on-farm research, in: Second European Workshop on Research Methodologies in Organic Farming, Bari, Italy.

Lockie S. (2002) 'The invisible mouth': mobilizing 'the consumer' in food production-consumption networks, Sociologia Ruralis 42, 278-294.

Lockie S., Halpin D. (2005) The Conventionalisation Thesis Reconsidered: Structural and Ideological Transformation of Australian Organic Agriculture, Sociologia Ruralis 45, 284-307.

Lockie S., Lyons K., Lawrence G. (2000) Constructing Green foods: corporate capital, risk, organic farming in Australia and New Zealand, Agr. Human Values 17, 315-322.

Loes A.K. (1990) Case Studies as a research method in ecological agriculture, in: Proceedings of the ecological agriculture No. 5, SLU, Uppsala. 
Lotter D., Seidel R., Liebhardt W. (2003) The performance of organic and conventional cropping systems in an extreme climate year, Am. J. Alternative Agr. 18, 146-154.

Lowrance R., Stinner B., Garfield J. (1984) Agricultural Ecosystems: Unifying Concepts, Wiley.

Lund V., Hemlin S., Lockeretz W. (2002) Organic livestock production as viewed by Swedish farmers and organic initiators, Agr. Human Values 19, 255-268.

Lynggaard K. (2001) The farmer within an institutional environment, Comparing Danish and Belgian organic farming, Sociologia Ruralis $41,85-111$.

MacMahon N. (2005) Biodynamic Farmers in Ireland, Transforming Society Through Purity, Solitude and Bearing Witness? Sociologia Ruralis 45, 98-114.

MacRae R.J., Hill S.B., Henning J., Mehuys G.R. (1990) Farm-scale agronomic and economic conversion from conventional to sustainable agriculture, Adv. Agron. 43, 155-198.

Mäder P., Dubois D., Gunst L., Fried P., Niggli U. (2002) Soil Fertility and Biodiversity in Organic Farming, Science 296(5573), 16941697.

Marinari S., Mancinelli R., Campiglia E., Stefano Grego S. (2006) Chemical and biological indicators of soil quality in organic and conventional farming systems in Central Italy, Ecol. Indicators 6, 701-711.

Marsden T. (2000) Food matters and the matter of food: towards a new food governance? Sociologia Ruralis 40, 20-29.

Marshall E.J.P., Moonen A.C. (2002) Field margins in Northern Europe: their functions and interactions with agriculture, Agr. Ecosyst. Environ 89, 5-21.

Martini E.A., Buyer J.S., Bryant D.C., Hartz T.K., Denison R.F. (2004) Yield increases during the organic transition: improving soil quality or increasing experience, Field Crop. Res. 86, 255-266.

Michelsen J. (2001) Recent Development and Political Acceptance of Organic Farming in Europe, Sociologia Ruralis 41, 3-20.

Moore O. (2006) Understanding postorganic fresh fruit and vegetable consumers at participatory farmers' markets in Ireland: reflexivity, trust and social movements, Int. J. Consumer Stud. 30, 416-426.

Morel B., Le Guen R. (2002), Une typologie compréhensive pour analyser la dynamique des producteurs biologiques, Séminaire INRADADP, Montpellier, 17-18/12/02.

Murdoch J., Miele M. (1999) Back to Nature, changing world of production, Sociologia Ruralis 39, 465-483.

National Research Council N. (1989) Alternative Agriculture, Washington.

Niggli U. (1999) Holistic Approaches in Organic Farming Research and Development, in: Zanoli R., Krell R. (Eds.), Research Methodologies in Organic Farming, Proceedings of the first SREN Workshop on Research Methodologies in Organic Farming, FAO\&FiBL, pp. 33-40.

Niggli U., Earley J., Ogorzalek K. (2007) Organic Agriculture and environmental stability of the food supply. Issues paper presented during the conference "Organic Agriculture and Food Security", 3-5 May 2007, FAO, Rome, Italy. ftp://ftp.fao.org/paia/organicag/ofs/OFS-2007-3-rev.pdf.

Noe E., Alrøe H. (2003) Farm enterprises as self-organizing systems: a new transdisciplinary framework for studying farm enterprises? Int. J. Sociol. Agr. Food 11, 3-14.

Noe E., Halberg N., Reddersen J. (2005) Indicators of Biodiversity and Conservational Wildlife Quality on Danish Organic Farms for use in Farm Management: a Multidisciplinary Approach to Indicator Management and Testing, J. Agr. Environ. Ethic. 18, 383-414.

Norman D.W., Malton P.J. (2000) Agricultural Systems Research and Technical Change, in: Colin J.-P., Crawford E.W. (Eds.), Research on Agricultural Systems: Accomplishments, Perspectives and Issues, Nova Science Publishers, Inc. Huntington, New York, pp. 17-47.

Obach B.K. (2007) Theoretical Interpretations of the Growth in Organic Agriculture: Agricultural Modernization or an Organic Treadmill? Soc. Nat. Resources 20, 229-244.

O'Riordan T., Cobb D. (2004) Assessing the Consequences of Converting to Organic Agriculture, J. Agr. Econ. 52, 22-35.

Ouedraogo A. (1998) Manger "naturel": les consommateurs de produits biologiques, Le Journal des Anthropologues 74, 13-27.

Padel S. (2001) Conversion to organic farming: a typical example of a diffusion of an innovation? Sociologia Ruralis 41.

Padel S. (2002) Studying conversion as a human activity system, <http;//orgprints.org/8374/> in: Powell, Jane et al. (Eds.), Proceedings of the UK Organic Research 2002 Conferece, Organic Centre Wales, Intitute of Rural Studies, University of Wales Aberystwyth, pp. 101-104.

Papadopoulos A., Mooney S.J., Bird N.R.A. (2006) Quantification of the effects of contrasting crops in the development of soil structure: an organic conversion, Soil Use Manag. 22, 172-179.

Petersen S., Axelsen J.A., Tybirk K., Aude E., Vestergaard P. (2006) Effects of organic farming on field boundary vegetation in Denmark, Agr. Ecosyst. Environ. 113, 302-306.

Piriou S. (2002) L'institutionnalisation de l'agriculture biologique (19802000), École Nationale Supérieure Agronomique de Rennes, Ph.D. Thesis.

Rasmussen I.A., Askegaard M., Olesen J.E., Kristensen K. (2006) Effects on weeds of management in newly converted organic crop rotations in Denmark, Agr. Ecosyst. Environ. 113, 184-195.

Reed M. (2001) Fight the future! How the contemporary campaings of the UK organic movement have arisen from their composting in the past, Sociologia Ruralis 41, 131-145.

Refsgaard K., Halberg N., Kristensen E. (1998) Energy utilization in crop and dairy production in organic and conventional livestock production systems, Agr. Syst. 57, 599-630.

Reganold J., Glover J., Andrews P., Hinman H. (2001) Sustainability of three apple production systems, Nature 410, 926-30.

Rigby D., Cáceres D. (2001) Organic farming and the sustainability of agricultural systems, Agr. Syst. 68, 21-40.

Robin P., Aeschlimann J.-P. (2007) Éléments de réflexion sur la formation agronomique et l'agriculture de demain, in: Robin P., Aeschliman J.P., Feller C. (Eds.), in: Histoire et Agronomie: entre ruptures et durée, IRD, Paris, pp. 457-474.

Roderick S. e. a. (2004) The Diversity of Organic Livestock Systems in Europe, in: Vaarst M. et al. (Eds.), Animal Health and Welfare in Organic Agriculture, CABI International, pp. 29-56.

Rosegrant M.W., Sulser T.B., Halberg N. (2006) Organic agriculture and food security, in: Proc. Joint Organic Congress, 30-31/05/06, Odense, Denmark, pp. 2-3.

Rosset P., Altieri M. (1997) Agroecology versus input substitution: A fundamental contradiction of sustainable agriculture, Soc. Nat. Resources 10, 283-295.

Ruault C. (2006) Le conseil en agriculture biologique: un analyseur des interrogations et évolutions du conseil en agriculture, in: Rémy J., Brives H., Lémery B. (Eds.), Conseiller en agriculture, Éducagri, pp. 183-203.

Salmona M. (1994) Les paysans français. Le travail, les métiers, la transmission des savoirs, L'Harmattan, Paris.

Sangar S., Abrol I.P. (2004) Conservation agriculture for transition to sustainable agriculture, Curr. Sci. 88, 686-687.

Sebillotte M. (1972) Pourquoi une enquête auprès des agriculteurs "biologiques" ? in: Berthou et al. (Eds.), L'agriculture biologique: éléments de diagnostic à partir d'une enquête sur 40 exploitations, Ronéo INA Paris-Grignon, 88 p. 
Sebillotte M. (1974) Agronomie et agriculture : essai d'analyse des tâches de l'agronome, Cahiers ORSTOM série Biol. 24, 3-25.

Sepannen L., Helenius J. (2004) Do inspection practices in organic agriculture serve organic values? A case study from Finland, Agr. Human Values 21, 1-13.

Sjursen H. (2001) Change of the weed seed bank during the first complete six-course crop rotation after conversion from conventional to organic farming, Biol. Agric. Hortic. 19, 71-90.

Smith E., Marsden T. (2004) Exploring the 'limits to growth' in UK organics: beyond the statistical image, J. Rural Studies 20, 345-357.

Spaargaren G. (1997) The ecological modernisation of production and consumption: Essays in environmental sociology, Unpublished doctoral dissertation, Wageningen Agricultural University.

Stanhill G. (1990) The comparative productivity of organic agriculture, Agr. Ecosyst. Environ. 30, 1-26.

Stassart P., Jamar D. (2005) Le Blanc Bleu Belge est-il soluble dans le bio? Nat. Sci. Soc. 13, 413-420.

Stolze M., Piorr A., Häring A., Dabbert S. (2000) The environmental impact of organic farming in Europe, in: Organic Farming in Europe: Economics and Policy, Vol. 6, University of Stuttgart-Hohenheim, Germany, 143 p.

Storstad O., Bjørkhaug H. (2003) Foundations of production and consumption of organic food in Norway: Common attitudes among farmers and consumers? Agr. Human Values 20, 151-163.

Sylvander B. (1997) Le rôle de la certification dans les changements de régime de coordination : l'Agriculture Biologique, du réseau à l'industrie, Rev. d'Économie Industrielle 80.

Sylvander B., Bellon S. \& Benoît M. (2006) Facing the organic reality: the diversity of development models and their consequences on research policies, in: Joint Organic Congress Organic Farming and Eur. Rural Development, Odense (DK), 2006/5/30-31.

Tovey H. (1997) Food, environmentalism and rural sociology: on the organic farming movement in Ireland, Sociologia Ruralis 37, 21-37.
Tovey H. (2002) Alternative agriculture movements and rural development cosmologies, Int. J. Soc. Agr. Food 10(1).

Tress B. (2001) Converting to organic agriculture-Danish farmers' views and motivations, Geografisk Tidsskrift 101, 131-143.

Trewavas A. (2004) A critical assessment of organic farming-and-food assertions with particular respect to the UK and the potential environmental benefits of no-till agriculture, Crop Prot. 23, 757-781.

USDA (1980) Report and recommendations on organic Farming, US Department of Agriculture, U.S. Government Printing Office, Washington D.C..

Van der Werf H., Petit J. (2002) Evaluation of the environmental impact of agriculture at the farm level: a comparison and analysis of 12 indicator-based methods, Agr. Ecosyst. Environ. 93, 131-145.

Vereijken P. (1997) A methodical way of prototyping integrated and ecological arable farming systems (I/EAFS) in interaction with pilot farms, Eur. J. Agron. 7, 235-250.

Verhoog H., Matze M., Lammerts E., Baars T. (2003) The Role of the Concept of the Natural (Naturalness) in Organic Farming, Agr. Human Values 16, 29-49.

Viel J.-M. (1979) L'agriculture biologique: une réponse? Entente, Paris.

Vos T. (2000) Visions of the middle landscape: Organic farming and the politics of nature, Agr. Human Values 17, 245-256.

Wynen E. (1996) Research Implications of a Paradigm Shift in Agriculture: The Case of Organic Farming, Resource and Environmental Studies, No. 12, Centre for Resource and Environmental Studies, Australian National University, Canberra, p. 46.

Zehnder G., Gurr G.M., Kühne S., Wade M.R., Wratten S.D., Wyss E. (2007) Arthropod Pest Management in Organic Corps, Annu. Rev. Entomol 52, 57-80.

Zundel C., Kilcher L. (2007) Organic agriculture and food availablity, in: Issues paper presented during the conference "Organic Agriculture and Food Security", 3-5 May 2007, FAO, Rome, Italy, ftp://ftp.fao.org/paia/organicag/ofs/OFS-2007-1.pdf. 